Makgoba, T. (2015). Ecclesiology and ethics: a critical self-reflection. The Ecumenical

Review, 67(4): 498-504

http://dx.doi.org/10.1111/erev.12191

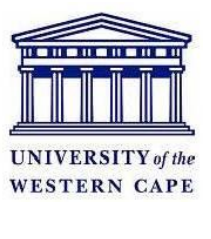

\title{
Ecclesiology and ethics: a critical self-reflection
}

Thabo Makgoba

Professor Conradie; Professor Lombard; Deputy Vice Chancellor, Academic and

Research; faculty; staff; Dean; Vice-Chancellor; distinguished guests, ladies and gentlemen, good morning. Thank you for the singular honour of being asked to welcome you and open this prestigious conference.

I want to start by acknowledging and congratulating my predecessor but one, Archbishop Emeritus Tutu, here present with us, and his family this morning. Arch, there is no one more deserving in this place to be honoured whilst alive with a chair and naming of an institute within an academic institution. We are proud of you, we love you, and feel privileged to have known and lived during your time. Ladies and gentleman let us give Archbishop Emeritus Tutu a round of applause and congratulate him on this great milestone as we congratulate the department too!

\section{TheContextof ThisConference}

One may locate this conference within three broad achievements, namely:

1. It concludes a three-year project on Ecclesiology and Ethics during which the Department of Religion and Theology hosted ten different workshops and conferences that resulted in various publications.

2. It is a celebration of Archbishop Emeritus Tutu and the announcement of the newly established Desmond Tutu Centre for Spirituality and Society, for which we give thanks to God and thank the university and the department.

3. It is an opportunity to honour selfless and hard-working academics and theologians. Thanks, Professor Lombard, Professor Conradie and Professor Cloete and your staff. 1

Welcome to you all at this celebratory conference that urges us to reflect on the past, our present, and the future, especially of theological education within a secular state. Perhaps your next conference theme should be a critical analysis of teaching theology within secular institutions.

\footnotetext{
${ }^{1}$ Many of the issues I raise here are dealt with in speeches and sermons available on my blog, http://archbishop.anglicanchurchsa.org/, and on the websites of the Anglican Church of Southern Africa, http://anglican-churchsa.org/, and the Archbishop Thabo Makgoba Development Trust, http://www.archmakgobadevtrust..co.za
} 


\section{SomeBriefReflections}

It is my earnest hope that in these three days under your chosen theme you will be robust in your interactions. I hope you will seek to address and find together what might be the language, the theological language and related praxis (actions and behaviour), as well as the requisite spirituality for African Christians in "such a time as this" (Esther 4:14). Ecclesiology and Ethics, or rather the interplay thereof, require a deeper understanding of our own identity as African Christians in particular and as Christians in general.

What might the nexus of ecclesiology and ethics beyond the 1997 call by the World Council of Churches (WCC) mean for us in Africa? Would this understanding help us in the mission and ministry of the global church and our own particular churches? How will and can the church live its true vocation and calling following this understanding of this nexus? In other words, if ethics is nothing else but the practical reality of the nature of God, how will we participate in the here and now in making this reality felt?

The challenge before us as we meet this week is whether we will find ways for the church to be faithful to its true vocation and identity. As you do this, let's be less dogmatic, but assume a posture that "the Kingdom of God is at hand but yet to come." This dialectical posture will help us move from a mere re-statement of the incarnate God (only) or the risen, ascended Lord, the Holy Spirit (only). It will help us see these as the triune God whose revelation is ongoing.

\section{Ethics as Revealing the Nature of God}

If ethics is to reveal the practical reality of the nature of God in the here and now through his (one) church, what do we say is the nature of (this) God? I leave this to systematic theologians and you all; but in broad strokes, we all agree and affirm from scripture and our experiences that God is love, God loves mercy and righteousness, God is just; and that Jesus and the Holy Spirit will lead us into all truth.

To cite my favourite Bible passage - all are favourite passages, depending on the lectionary readings, but John 10:10 is one of those - Jesus came to reveal the nature of God, a generous God, so that "we may have life and have it abundantly." Not some, but all. Then there is the last chapter of Mathew, where Jesus says, go into the world, baptising all, making disciples of all people and I, through the Holy Spirit, will be with you to the end of time.

Therein lies our identity: spiritedness. However, we are not alone. That same spirit that raised Jesus from the dead is at work with us. We are sent into God's world, God is with us. And wherever we are sent, we are to reveal God's nature: justice, love, mercy, compassion, forgiveness, and truth.

The church exists in mission. This missiological self-understanding is key if we are not only to understand the theological framework of ecclesiology and ethics, but if we are to live these in reality. 


\section{Praxis, What of Praxis?}

Archbishop Emeritus Tutu will agree with me when I cite his mentor and former Archbishop Trevor Huddleston, who in his book Naught for Your Comfort voiced his exasper- ation with "Words, words, words..."2 Lest Trevor chastise me from the dead, let me make my call to action. Kenneth Kaunda aptly states my call for praxis as follows: "What nations need more than anything else, is not a Christian ruler in the palace but a Christian prophet within earshot."3

At this conference you will need to answer the question of whether in our context today there are intelligent prophets within earshot? Are we as the body of Christ, the church, moving closer together, or are we walking apart in silos? Are we just guarding our denominational imperialism, peculiarities, and suspicion of each other's intentions, past and future?

Are we boldly and resolutely seeking the truth of Christ in our witness, or comfortable in relating to each other at arm's length? I can't recall who it was, but it might have been the Ecumenical Patriarch Bartholomew, who said that "the self-sufficient church that lives to itself, dies to itself." I want to suggest that especially after revolutions that lead to democracy in Africa, the church has withdrawn from public life and became "churchy."

Your theme requires that we reflect on our vocation in the African continent.

I cannot speak for the continent as a whole. However I can speak as Primate for six nations - Angola, Lesotho, Namibia, Mozambique, Swaziland, and not least the Republic of South Africa - and we also belong to the Council of Anglican Provinces of Africa (CAPA), which is an Anglican response within the continent. CAPA tries to collaborate with the All Africa Conference of Churches, but on the whole we concentrate on co-ordinating a solely Anglican response and not an ecumenical one. We can improve this denominational response and collaborate more within the ecumenical movement.

In South Africa, I preside over the Ecumenical Foundation of South Africa (EFSA), the National Church Leaders' Council, and the South African Council of Churches' (SACC) national church leaders' forums. I am grateful to EFSA that when the SACC was "hospitalized" by the democratic dividends of the country, EFSA upheld the ecumenical mandate, witness, and co-ordination as we held up a light to South Africa's ills. The SACC is now "recuperating" and hopefully that ecumenical body will again help us to live out our faith in society the way it did previously.

The key challenge of our theme is: Are we effective and faithful in addressing our unity in Christ, or are we just resuscitating structures for their own ends?

\footnotetext{
2 Trevor Huddleston, Naught for Your Comfort (London: William Collins, 1956).

${ }^{3}$ Quoted by Philip Yancey, What's So Amazing about Grace (Grand Rapids, Mich.: Zondervan, 1997).
} 
In the Western Cape, Archbishop Brislin of the Catholic Church and I are patrons of an effective inter-religious body, the Western Cape Religious Leaders' Forum, the focus of which is ecumenical and inter-religious witness. However, for me the WCRLF has been the glue that has held together differing complexions within Christianity and with other faiths.

In South Africa, even given these key structures, I have a concern about an issue that seems to undermine our strength and unique vocation. We seem within democratic South Africa to want proximity to power, money, status, and the ruling parties; we want to relegate ourselves to receiving government hand-outs. We are "in the upper room, doors shut" in fear of the ruling elite. There are few with intelligent prophecy willing to say, "thus says the Lord, the ruling party is in a moral quandary!" This is evident from recent scandals, its own exoneration of itself from corruption, its seeking to have private talks with the Afrikaans-speaking churches and the SACC. We need to help, as a united church, to recalibrate the moral compass of our leaders, for though they are democratically elected they are steadily losing the moral credibility to lead South Africans, especially of faith.

Lest it sound as if I am making an African conference focus on only on South Africa, let me share with you and excerpt from my Pentecost sermon in which we also celebrated Africa Day. 4

I am emboldened by the words of the prophet Ezekiel and by the spirit of truth to speak truth not only to the powerful in South Africa, but as an African to address fellow Africans from other parts. On Africa Day we have much to celebrate. But we also have much to repent of and much to grieve over. In West Africa, we have been excited to see that Liberia has now been declared Ebola-free, and thrilled at the success of the elections in Nigeria, which have seen a peaceful transfer of power in what are being described as the most successful elections in the country's history. But we must continue to pray for an end to the atrocities of Boko Haram and for the release of all those - especially the women and girls - who have been abducted. Coming at a time when our Pan African Parliament is focusing on the empowerment of women, it is a scandal that the international response to the news of the rape and enslavement of the women and girls held hostage is so muted.

In Mali and the Central African Republic (CAR) we must welcome the steps that leaders are making toward peace - and especially for the release by militia in the CAR of child soldiers - but we must also pray for the strengthening of the peace processes in those countries. In East Africa, we mourn the victims of extremist attacks in Kenya and Somalia, and deplore the short-sightedness of the leaders of South Sudan in pursuing their futile and destructive political wrangling at the cost of their people's lives. And in Burundi, we weep at how Madiba's legacy as the broker of the Arusha peace agreement of 2000 is being squandered by leaders whose actions may well return the country to civil war.

\footnotetext{
${ }^{4}$ Sermon for the Day of Pentecost, 2015, St Monnica’s Church Midrand.
} 
Across Africa as a whole, we must celebrate the growing acceptance of the positive narrative that says "Africa is rising" - but we have to work to ensure that the benefits of growing economies in many parts are not hogged by elites but are shared among all. But let me end this catalogue of the challenges that face our continent on a positive note. How do we end poverty in Africa? How do we end income inequality? Well, one thing we can do is to support the campaign to end the illicit flow of money out of Africa, which is robbing us of billions of dollars a year. Former President Mbeki presented us this week with a report showing how we can end these flows and release money that, if used properly, would help put Africans in a position to take care of themselves. For this crucial work, we own him a debt of considerable gratitude.

These are examples that I also shared on May 26, at the Pan African Parliament in celebrating Africa Day in Midrand.

\section{Conclusion}

I want to conclude these welcoming remarks with the questions that we need to raise further and address at this conference.

Do we turn a blind eye to continental problems, including the crisis of many Africans fleeing our continent and dying in the Mediterranean in search of a better life? What of Africa's unemployed youth? Do we avoid addressing these issues because that may be perceived as meddling in politics?

Do we rather prefer to be so heavenly minded that we are of no earthly use? Spare your thoughts for HIV/AIDS, for migrants, and for what I call the new struggle in which we act collectively and with courage to root out inequality. To help me pray for this courage, I am reading Paul Tillich's book The Courage to Be.5

My final question is this: When can and should the church withdraw its moral support of a legitimately and democratically elected government?

I thank you! Welcome!

God Bless Africa.

\footnotetext{
${ }^{5}$ Paul Tillich, The Courage to Be (New Haven: Yale University Press, 2014).
} 